\title{
Inisiasi Gerakan Shodaqoh Sampah Bagi Masyarakat Desa Trimurti, Bantul
}

\author{
Initiation of Waste Almsgiving Movement for Trimurti Village Community, Bantul \\ Arie Kusuma Paksi ${ }^{1}$, Nanik Prasetyoningsih ${ }^{2}$ \\ Universitas Muhammadiyah Yogyakarta, Yogyakarta \\ 1ariekusumapaksi@,umy.ac.id, ${ }^{2}$ nprasetyoningsih@gmail.com
}

Riwayat Artikel: Dikirim 23 Juni 2019; Diterima 18 November 2019; Diterbitkan 30 November 2019

\begin{abstract}
Abstrak
Terkait dengan tema pengabdian masyarakat, ternyata di masyarakat Desa Trimurti masih sangat perlu sosialisasi mengenai bahaya tumpukan sampah, hasil dari aktivitas rumah tangga, yang akan mengalami dekomposisi dan menghasilkan gas $\mathrm{CH}_{4}$ dan $\mathrm{CO}_{2}$ yang berdampak pada pemanasan global. Pengabdian dilakukan dengan maksud untuk memberikan informasi yang akurat untuk meningkatkan pemahaman masyarakat Desa Trimurti mengenai pentingnya mengelola sampah rumah tangga dalam rangka mengurangi resiko pemanasan global. Permasalahan yang ditemukan adalah sebagai berikut: (1) Pemahaman masyarakat mengenai bahaya pemanasan global masih perlu ditingkatkan, (2) Kesadaran masyarakat masih rendah mengenai pentingnya mengelola sampah rumah tangga; dan (3) Belum adanya manajemen pengelolaan sampah yang inovatif. Adapun penyelesaian masalah yang ditawarkan adalah sebagai berikut: (1) Peningkatan kesadaran masyarakat bahwa menjaga lingkungan melalui pengelolaan sampah, akan berdampak pada pengurangan resiko pemanasan global. Ini menjadi tanggungjawab semua warga, dan bukan hanya pemerintah; (2) Motivasi dan sosialisasi mengenai pentingnya menjaga lingkungan sekitar khususnya bagi masing-masing rumah tangga; dan (3) Pendampingan Pemerintah Dukuh untuk melakukan sosialisasi prosedur pengelolaan sampah melalui program shodaqoh sampah. Pelaksanaan kegiatan dilaksanakan di Dukuh Gerso, dan telah dilaksanakan dengan baik bekerjasama dengan Masyarakat Dukuh Gerso dan Pemerintah Desa Trimurti. Hasil pelaksanaan kegiatan antara lain: pengetahuan dan pemahaman masyarakat Desa Trimurti mengenai pentingnya menjaga lingkungan sekitar meningkat, yakni dengan dibentuknya Gerakan Pengelola Sampah di setiap RT dibawah Koordinasi Kepala Dukuh Gerso dan di ketuai langsung oleh Ketua RT. Inisiasi program shodaqoh sampah masih berlangsung di Dukuh Gerso, dan oleh pihak Desa akan disebarkan ke padukuhan yang lainnya di Desa Trimurti. Sementara itu, pelaksanakan gerakan shodaqoh sampah di Dukuh Besole baru sebatas inisiasi dikarenakan Kepala Dukuh dan warga masyarakat sedang mempersiapkan langkah-langkah selanjutnya demi memulai gerakan pengelolaan sampah dengan model tersebut.
\end{abstract}

Kata kunci: shodaqoh sampah; kesehatan lingkungan; pemanasan global

\begin{abstract}
Related to the theme of community service, it turns out that in the community of Trimurti Village there is still a great need for socialization regarding the dangers of garbage piles, the result of household activities, which will experience decomposition and produce $\mathrm{CH} 4$ and $\mathrm{CO} 2$ gas and this will have an impact to global warming. Dedication was carried out with the intention of providing accurate information to improve the understanding of the Trimurti Village community about the importance of managing bousehold waste in order to reduce the risk of global warming. The problems found are as follows: (1) Public understanding of the dangers of global warming still needs to be improved, (2) Public awareness is still low regarding the importance of managing household waste; and (3) The absence of innovative waste management. The solutions to the problems offered are as follows: (1) Increasing public awareness that protecting the environment through waste management will have an impact on reducing the risk of global warming. This is the responsibility of all citizens, and not just the government; (2) Motivation and socialization regarding the importance of protecting the surrounding environment, especially for each household; and (3) Assistance to the bamlet government to disseminate waste management procedures through the waste almsgiving program. The activity was carried out in Gerso Hamlet, and has been well implemented in collaboration with the Dukub Gerso community and the Trimurti Village Government. The results of the implementation of the activities included: the knowledge and understanding of the Trimurti Village community about the importance of protecting the surrounding environment, namely the establishment of the waste management movement in each neighborhood under the coordination of Gerso Hamlet Heads and chaired directly by the Chairperson of the Neighborhood. The initiation of the waste almsgiving program is still ongoing in Gerso Hamlet, and by the Village will be distributed to other hamlets
\end{abstract}


in Trimurti Village. Meanwhile, carrying out the waste almsgiving movement in Hamlet Besole was only limited to initiation because the Village Head and the community were preparing the next steps to start the waste management movement through almsgiving programme.

Keywords: waste almsgiving, environmental health, global warming

\section{PENDAHULUAN}

Desa Trimurti terletak di wilayah Kecamatan Srandakan, Kabupaten Bantul, Daerah Istimewa Yogyakarta, yang terdiri atas 19 Pedukuhan dan meliputi 135 RT. Desa Trimurti merupakan desa penggabungan dari tiga Desa/Kelurahan yaitu Desa Mangiran, Srandakan, dan Puron.

Desa Trimurti yang dikenal sebagai daerah karangkopek, letaknya sangat strategis karena dilalui oleh jalur lintas selatan, jalan propinsi yang menghubungkan jalan di bagian selatan Pulau Jawa, Desa Trimurti. Desa Trimurti merupakan salah satu wilayah desa di Kabupaten Bantul yang terletak di perbatasan kabupaten yaitu Kabupaten Kulon Progo. Jarak tempuh Desa Trimurti $200 \mathrm{~m}$ dari Kecamatan Srandakan, $12 \mathrm{~km}$ dari Pemerintah Kabupaten Bantul dan $24 \mathrm{~km}$ dari Pemerintah Propinsi D.I Yogyakarta.

Cakupan Wilayah Desa Trimurti terdiri dari 19 wilayah Pedukuhan, antara lain Pedukuhan Srandakan; Pedukuhan Gerso; Pedukuhan Klurahan; Pedukuhan Proketen; Pedukuhan Jetis; Pedukuhan Sawahan; Pedukuhan Puron; Pedukuhan Puluhan Lor; Pedukuhan Puluhan Kidul; Pedukuhan Pedak; Pedukuhan Gunungsaren Kidul; Pedukuhan Gunungsaren Lor; Pedukuhan Nengahan; Pedukuhan Lopati; Pedukuhan Bendo; Pedukuhan Celan; Pedukuhan Cagunan; Pedukuhan Mangiran; Pedukuhan Sapuangin. Sementara Rukun Tetangga (RT) di desa Trimurti ada 135 RT.

Berdasarkan analisis terkait dengan tema pengabdian masyarakat, ternyata di masyarakat Desa Trimurti masih sangat perlu sosialisasi mengenai bahaya pemanasan global yang kaitannya dengan pengelolaan sampah.
Bicara permasalahan sampah, kecenderungannya adalah banyak warga masyarakat yang tidak terlalu memikirkan apakah sampah yang kita hasilkan itu organik atau non-organik. Warga masyarakat juga tidak terlalu peduli kemana larinya sampah tersebut. Sementara kenyataannya, di Indonesia sampah rumah tangga akan bercampur dengan jutaan sampah rumah tangga yang lain, hingga terbentuklah gunung-gunung sampah yang tak semestinya di Tempat Pembuangan Akhir (TPA) berbagai kota.

Seperti sering kita temui, sebagian besar warga masyarakat membuang sampah sembarangan, sehingga hal tersebut dapat mencemari lingkungan dan merusak ekosistem makhluk hidup lainnya.

Permasalahan sampah sesungguhnya permasalahan warga masyarakat secara bersama. Hal ini karena setiap warga masyarakat memiliki andil dalam produksi sampah yang ada dalam kehidupannya. Dengan demikian, setiap warga masyarakat sesungguhnya bertanggungjawab terhadap sampah yang telah diproduksinya, sehingga sampah itu tidak mempunyai dampak buruk bagi kehidupan warga masyarakat secara luas. Setiap warga masyarakat seharusnya dapat berlaku wise (bijak) dalam memperlakukan sampah, tidak sembarang membuangnya sehingga berdampak buruk bagi kehidupan ekosistem makhluk hidup di sekitarnya.

Selanjutnya, penyelesaian masalah sampah tidak dapat diselesaikan dari aspek hilirnya saja, yang dengan membuat TPA atau tempat pengolahan sampah yang sejenis, tetapi harus dilakukan melalui pendekatan di hulu, melalui upaya penyadaran setiap warga masyarakat untuk ikut serta dalam mengelola sampah yang diproduksi oleh lingkungannya. 
Sampah adalah sisa kegiatan sehari-hari manusia dan/atau proses alam yang berbentuk padat. Akibat proses alam setiap manusia sudah pasti menghasilkan timbunan sampah dan berpotensi sebagai penghasil sampah.

Selanjutnya, pemanasan global adalah kondisi peningkatan suhu rata-rata di bumi karena akibat konsentrasi gas rumah kaca yang berlebihan, baik pada lapisan atmosfer, daratan, maupun lautan. Pemanasan gobal ini diakibatkan dari peningkatan jumlah karbondioksida, efek rumah kaca, serta aktivitas manusia lainnya termasuk penumpukan dan pembakaran sampah sembarangan atau sampah yang tidak di kelola dengan benar.

Oleh karnanya, kegiatan pengelolaan sampah yang tepat sangat perlu di perhatikan serta sosialisasi untuk menggalakkan pengelolaan sampah yang berkelanjutan, agar kegiatan ini dapat berlangsung secara berkelanjutan.

Pengabdian ini dilakukan dengan maksud untuk memberikan informasi yang akurat untuk meningkatkan pemahaman masyarakat Desa Trimurti mengenai pengelolaan sampah yang tepat untuk mengurangi resiko-resiko pemanasan global.

Berdasarkan observasi dan wawancara dengan pejabat pedukuhan setempat, terdapat beberapa permasalahan sampah di Desa Trimurti, diantaranya pegelolaan sampah yang kurang baik di lingkungan warga, kurangnya kesadaran warga masyarakat dalam kepeduliannya terhadap lingkungan sekitar terutama kaitannya dengan sampah rumah tangga, prilaku dan pola hidup warga masyarakat yang masih mengarah bahwa sampah adalah sesuatu yang membebani pengelola kebersihan, dan paradigma warga masyarakat bahwa sampah adalah sesuatu yang sudah tidak ada gunanya.

Mengacu pada poin yang disampaikan di atas, tabel berikut berusaha memetakan beberapa permasalahan dan usulan-usulan dalam penyelesaian permasalahan mengenai sampah berdasarkan. Adapun dalam setiap penyelesaian permasalahan, warga masyarakat akan selalu dilibatkan agar senantiasa lebih mengetahui permasalahan yang ada dan cara penanganannya. Keterlibatan partisipatoris warga masyarakat merupakan cara pemberdayaan masyarakat yang tepat agar penanganan sampah dapat berlangsung secara berkelanjutan.

Tabel 1.

Permasalahan dan Solusi

\begin{tabular}{|c|c|}
\hline $\begin{array}{c}\text { Permasalahan } \\
\text { yang ditemukan }\end{array}$ & Solusi yang ditawarkan \\
\hline $\begin{array}{l}\text { Pemahaman warga } \\
\text { masyarakat } \\
\text { mengenai bahaya } \\
\text { pemanasan global } \\
\text { (global warming) } \\
\text { masih perlu } \\
\text { ditingkatkan. }\end{array}$ & 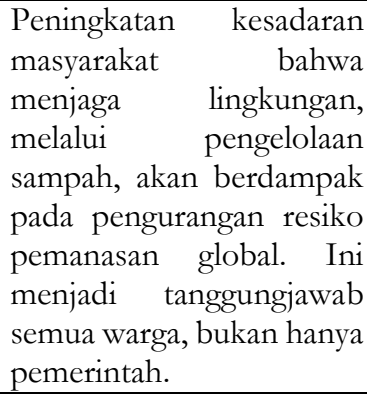 \\
\hline $\begin{array}{l}\text { Kesadaran warga } \\
\text { masyarakat masih } \\
\text { rendah mengenai } \\
\text { pentingnya } \\
\text { mengelola sampah } \\
\text { rumah tangga. }\end{array}$ & $\begin{array}{l}\text { Motivasi dan sosialisasi } \\
\text { mengenai pentingnya } \\
\text { menjaga lingkungan } \\
\text { sekitar khususnya bagi } \\
\text { masing-masing rumah } \\
\text { tangga }\end{array}$ \\
\hline $\begin{array}{lr}\text { Belum } & \text { adanya } \\
\text { manajemen } & \\
\text { pengelolaan } & \\
\text { sampah } & \text { yang } \\
\text { inovatif } & \end{array}$ & $\begin{array}{l}\text { Pendampingan } \\
\text { Pemerintah Dukuh untuk } \\
\text { melakukan sosialisasi } \\
\text { prosedur pengelolaan } \\
\text { sampah melalui program } \\
\text { shodaqoh sampah. }\end{array}$ \\
\hline
\end{tabular}

Pemahaman warga masyarakat yang salah terhadap sampah dan rendahnya pemahaman warga masyarkat mengenai bahaya pemanasan global, maka akan berdampak pada perlakuan yang salah pula terhadap sampah. Sebagian besar warga masyarakat masih menganggap sampah sebagai musuh yang harus di perangi dan di jauhi, sehingga masih banyak yang menyianyiakan sampah, bahkan banyak juga yang tidak menyadari kebermanfaatan sampah atau limbah-limbah rumah tangga. Kebiasaan membakar, menghanyutkan ke sungai, dan membuang sampah sembarangan menjadi kebiasaan buruk yang masih dilakukan oleh banyak warga 
masyarakat. Perilaku ini muncul dikarenakan rendahnya pemahaman dan kesadaran akan makna dan fungsi sampah, yang sesunguhnya dapat dijadikan sebagai sumberdaya yang bernilai yang dapat diolah dan digunakan sebagai barang-barang berharga dan bermanfaat.

Sampah dapat menjadi barang berharga jika dilakukan pemilahan sesuai dengan jenis sampah, yaitu sampah kertas, sampah plastik, dan sampah logam/gelas. Sampah yang telah terpilah merupakan bahan baku (raw materials) yang ditunggutunggu oleh perusahaan-perusahaan daur ulang. Perusahaan kertas membutuhkan sampah kertas, perusahaan plastik membutuhkan sampah plastik, perusahaan logam membutuhkan sampah logam, dan perusahaan gelas membutuhkan sampah beling/kaca. Hampir semua jenis sampah anorganik dapat di jual dan diambil manfaatnya kembali oleh perusahaan melalui pengepul, sehingga sampah tersebut dapat diketahui harganya. Mengelola sampah dengan baik dan benar, tidak hanya berdampak pada pelestarian ekosistem makhluk hidup, tetapi juga dapat dijadikan sumber kebaikan dengan menjadikannya sebagai alat untuk beramal dan bershadaqoh. Melalui gerakan peduli sampah warga masyarakat selain dapat membantu pengelolaan sampah di lingkungannya, juga dapat beramal dan bersedekah dengan menyumbangkan sampah yang dimilikinya pada badan amal yang ada atau melalui bank sampah yang ada di sekitar lingkungan.

Menurut Undang-Undang Nomor 18 Tahun 2008 tentang Pengelolaan Sampah, terdapat tiga jenis sampah yang dapat dikelola, yaitu: sampah rumah tangga; sampah sejenis sampah rumah tangga, dan sampah spesifik. Sampah rumah tangga berasal dari kegiatan sehari-hari dalam rumah tangga, tidak termasuk tinja dan sampah spesifik. Sampah sejenis sampah rumah tangga berasal dari kawasan komersial, kawasan industri, kawasan khusus, fasilitas sosial, fasilitas umum, dan/atau fasilitas lainnya. Sampah spesifik meliputi: a. sampah yang mengandung bahan berbahaya dan beracun; b. sampah yang mengandung limbah bahan berbahaya dan beracun; c. sampah yang timbul akibat bencana; d. puing bongkaran bangunan; e. sampah yang secara teknologi belum dapat diolah; dan/atau f. sampah yang timbul secara tidak periodik.

Selanjutnya, pengabdian ini dilaksanakan dalam rangka membangun gerakan publik kesadaran masyarakat untuk meningkatkan pemahaman, kesadaran, dan kepedulian masyarakat desa Trimurti dalam pengelolaan sampah. Dalam kurun 10 dekade komposisi sampah plastik naik 5\%, apabila tidak ada perubahan perilaku masyarakat dan upaya-upaya revolusioner, tahun 2050 diperkirakan komposisi sampah plastik mencapai 40\%. Oleh karnanya, sosialisasi yang dilakukan dalam pengabdian ini adalah dengan sistem pendekatan agama dan kebersamaan masyarakat yaitu sistem shadaqah sampah yang merupakan upaya pendekatan dalam perubahan perilaku publik dengan menggunakan strategi pendekatan keagamaan dan lembaga keagaamaan, khususnya Islam, dalam menggerakan warga masyarakat untuk mengurangi sampah sebagai cara mengamalkan salah satu prinsip ajaran Islam, yaitu kebersihan.

Ajakan shadaqah sampah merupakan solusi konkret menerapkan prinsip pengelolaan sampah yang berkelanjutan karena didasarkan pada penyelarasan tiga pilar, yaitu lingkungan, sosial, dan ekonomi juga di dasarkan pada ajaran agama Islam tentang kebersihan yang menjadi sebagian dari prilaku keimanan seseorang.

\section{METODE}

Metode yang digunakan untuk memberikan pemahaman yang utuh mengenai tata acara pengelolaan sampah untuk mengurangi resiko pemanasan global adalah dengan cara melakukan sosialisasi dan penyuluhan mengenai pentingnya menjaga lingkungan sesuai dengan tema yang dimaksud. 
Disamping itu, sebagai upaya kebermanfaatan jangka panjang kegiatan, maka pelaksanaan program shodaqoh sampah sangat penting untuk dilakukan.

Metode pelaksanaan kegiatan PPDM direncanakan dan dilaksanakan berdasarkan pada evaluasi atas kondisi warga masyarakat yang kurang memahami bahaya pemanasan global. Hal ini dibuktikan dengan banyaknya timbunan sampah yang sering di temui baik di perkotaan maupun di pedesaan tanpa adanya pengelolaan yang terpadu dan terus menerus yang terjadi secara turun-menurun. Padahal timbunan sampah dapat menimbulkan emisi gas $\mathrm{CH}_{4}$ dan $\mathrm{CO}_{2}$ yang semakin besar dan berpengaruh yang sangat signifikan terhadap fenomena pemanasan global.

Terkait dengan pengelolaan sampah tersebut, warga masyarakat Desa Trimurti juga cenderung acuh tak acuh dan abai terhadap lingkungan sekitar. Dengan dalih bahwa selama sampah tidak berpengaruh terhadap kesehatan dan keselamatan anggota keluarganya, maka tumpukan sampah tersebut tidak menjadi persoalan untuk mereka.

Sementara itu, inovasi dalam pengelolaan sampah perlu dilakukan dalam rangka merubah cara berfikir dan perilaku warga masyarakat dan sekaligus memitigasi resiko pemanasan global melalui gerakan pengelolaan sampah yang mengandung unsur ibadah, amal jariyah, saling tolongmenolong (ta'awun), dan saling menanggung (takaful) di dalamnya.

Kegiatan PPDM menggunakan metode penyuluhan lisan atau berbentuk ceramah dan pendampingan. Penyuluhan mengenai pengaruh sampah terhadap lingkungan, penyuluhan dan pelatihan pemanfaatan dan pemilahan sampah rumah tangga, dan penyuluhan mengenai shodaqoh sampah. Penyuluhan yang dilakukan adalah mengundang pemateri yang berpengalaman dan berkompeten seperti pemateri dari Dinas Lingkungan Hidup, dari penggagas shodaqoh sampah Kampung Brajan. Untuk program shodaqoh sampah, dilakukan penyuluhan mengenai konsep shodaqoh sampah itu sendiri dan bagaimana penerapannya. Program menggunakan metode pendampingan yaitu pendampingan pembentukan pengelola shodaqoh sampah dan field trip ke lokasi pengelolaan shodaqoh sampah.

Gambar 1.

Konsep Kegiatan KKN- PPDM

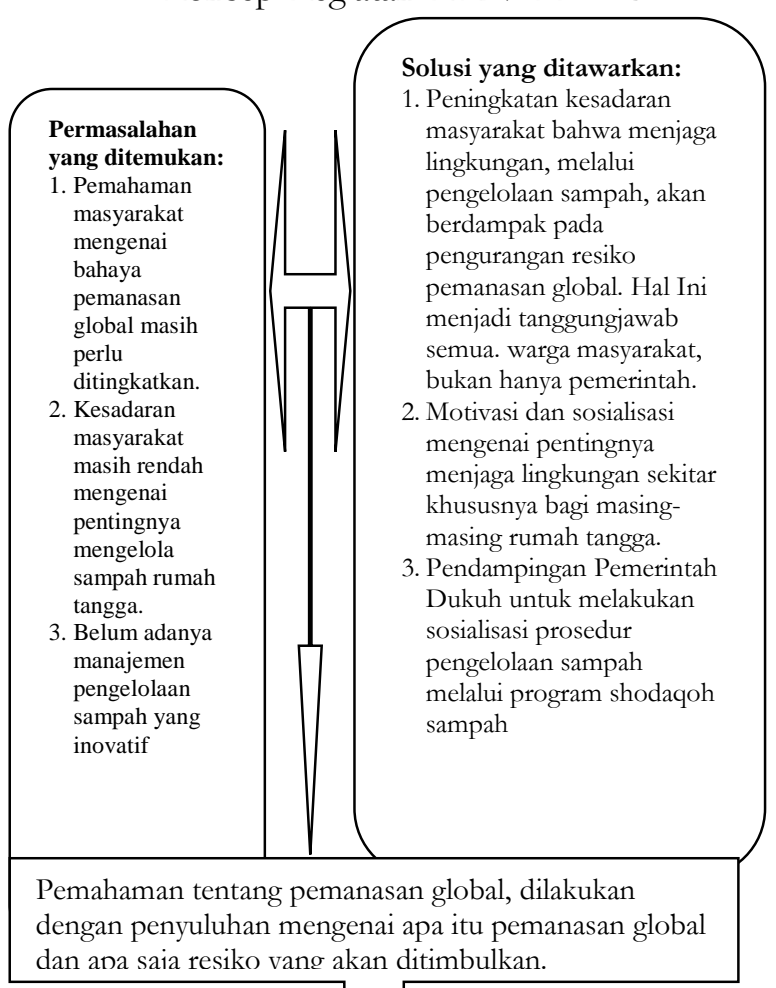

Pemahaman mengenai pentingnya menjaga lingkungan, dilakukan dengan Penyuluhan lingkungan kepada masyarakat.

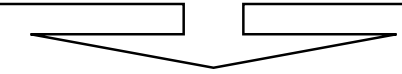

Inisiasi program shodaqoh sampah.

\section{HASIL DAN PEMBAHASAN}

Hasil

Pada era sekarang banyak kita temui, sebagian besar warga masyarakat masih rendah pemahamannya dalam pengelolaan sampah rumah tangga. Banyak warga masyarakat yang tidak menyadari terdapat dampak yang serius dari pengelolaan sampah yang tidak tepat yakni pemanasan 
global. Hingga saat ini pemanasan global memang menjadi salah satu isu yang tidak boleh tertunda lagi untuk segera di cari pencegahannya.

Dewasa ini shodaqoh sampah telah digalakkan oleh organisasi kemasyarakatan termasuk organisasi keagamaan Muhammadiyah. yang berkomitmen untuk terus mengembangkan gerakan pengelolaan lingkungan yang telah dirintis sejak hampir satu dekade terakhir. Sementara itu wujud nyata dari pelaksanaan pengelolaan lingkungan tersebut dilakukan melalui, salah satunya, gerakan shodaqoh sampah yang dikembangkan oleh Majelis Lingkungan Hidup Muhammadiyah.

Oleh karena itu, demi memperluas cakupan program tersebut, kegiatan pengelolaan sampah melalui inisiasi gerakan shodaqoh sampah di lakukan di Desa Trimurti, khususnya di Dukuh Gerso dan Dukuh Besole Srandakan. Dukuh Gerso dan Dukuh Besole merupakan dua dukuh bagian dari desa Trimurti yang notabene warga masyarakatnya masih kurang pemahamannya tentang pentingnya pengelolaan sampah yang benar dan kebermanfaatan sampah. Adapun tahapantahaoan pelaksanaan program inisasi gerakan shodaqoh sampah dapat dijelaskan sebagai berikut:

\section{Penyuluhan mengenai pengaruh sampah terhadap lingkungan}

Penyuluhan dilakukan dengan beberapa kunjungan mulai koordinasi dengan tokoh masyarakat dan tokoh agama di Dukuh Gerso dan Dukuh Besole Srandakan. Selanjutnya dilakukan sosialisasi dengan warga masyarakat pada tanggal 19 April 2019 dan dilanjutkan praktek pengumpulan dan pemilahan sampah rumah tangga pada tanggal 20 April 2019.

Penyuluhan atau sosialisasi adalah langkah pertama yang dilakukan untuk menerangkan dan mengajak partisiapasi warga masyarakat untuk mau mengelola sampah bersama-sama demi kemajuan dan kebersihan lingkungan. Setelah proses sosialisasi, untuk menambah pemahaman warga masyarakat, dilakukan praktek langsung.

Kegiatan penyuluhan ini dilakukan di Dukuh Gerso dan Dukuh Besole dengan memberikan gambaran dampak dan bahaya serius tentang sampah apabila tidak dilakukan perlakuan yang benar, lebih-lebih melakukan pembuangan dan pembakaran sampah sembarangan. Penyuluhan ini juga memberikan wacana dan ajakan untuk memberdayakan lingkungan bersih dengan pendekatan amal jariyah yaitu dengan kegiatan shodaqoh sampah.

Sampah adalah sesuatu yang sudah tidak ada manfaatnya dan menjadi hal yang tidak dapat dihindari oleh manusia, karna seiring kita melakukan konsumsi sudah pasti akan menimbulkan sampah. Namun demikian, sampah akan menjadi hal yang bermanfaat apabila dikelola dengan benar dan tepat, yaitu dengan memilih dan memilah sampah sesuai dengan jenisnya basah dan kering.

Sementara shodaqoh merupakan salah ibadah horizontal skaligus vertikal. Oleh karnanya shodaqoh merupakan ibadah yang sangat bermanfaat dan bermakna bagi diri sendiri maupun lingkungan apabila dilakukan dengan benar dan menjadi kebiasaan dalam sehari-hari. Shodaqoh tidak harus dilakukan dengan menyerahkan sejumlah uang, namun ada beberapa cara bagaimana kita dapat memberikan shodaqoh termasuk dengan memberikan apa yang kita punya untuk diambila manfaatnya.

Selanjutnya, pada tanggal 20 April 2019 dilakukan praktek bagaimana langkahlangkah pengelolaan sampah dengan benar. Dalam gerakan Shodaqoh Sampah, sampah rumah tangga dipilah kedalam tiga kelompok, sampah kertas, sampah plastik (kresek, kantong plastik dan sejenisnya), dan sampah keras/logam (kaleng minuman/susu, botol minuman berbahan plastik/kaca, gelas berbahan plastik/kaca, botol shampo, potongan besi, paku, peralatan rumah tangga berbahan 
aluminium/tembaga/baja/besi/plastik, pecahan kaca bening, mainan anak-anak berbahan logam $/ \mathrm{kaca} /$ plastik yang tebal dan keras). Warga masyarakat atau pemberi Shodaqoh memilah dan memasukkan sampah dalam kondisi bersih setiap kali menghasilkan sampah ke dalam masingmasing karung/kresek sesuai jenisnya. Setelah dilakukan pemilahan, maka selanjutnya disetor ke pengelola.

Kegiatan shodaqoh sampah di Dukuh Gerso dan Dukuh Besole Kecamatan Srandakan mendapatkan antusias yang baik dari warga masyarakat. Hal ini dapat dilihat dari banyaknya warga masyarakat yang hadir dan mengikuti kegiatan sosialisasi dan praktek langsung shodaqoh sampah. Bentuk partisipasi warga masyarakat ini mempunyai peran yang vital dalam membantu melanjutkan kegiatan shodaqoh sampah di Dukuh Gerso dan Dukuh Besole. Penyuluhan ini dilakukan dengan memberikan wawasan gambaran pengelolaan shodaqoh sampah serta dampak sampah rumah tangga apabila tidak di kelola dengan baik dan benar. Selanjutnya, memberikan gambaran bagaimana pelaksanaan shodaqoh sampah oleh warga masyarakat. nantinya.

Kegiatan pengumpulan dan pemilahan sampah secara langsung atau secara parsipatoris oleh warga masyarakat yang di kelola oleh pengurus. Hal ini dilakukan bertujuan agar masyarakat memiliki pemahaman yang langsung melekat bagaimana pengelolaan sampah yang tepat dan tidak hanya menjadi wacana belaka.
Berikut dokumentasi sosialisasi dan penyerahan timbangan di Dukuh Besole Srandakan.

Gambar 2.

Dokumentasi Sosialisasi Shodaqoh Sampah di Dukuh Besole

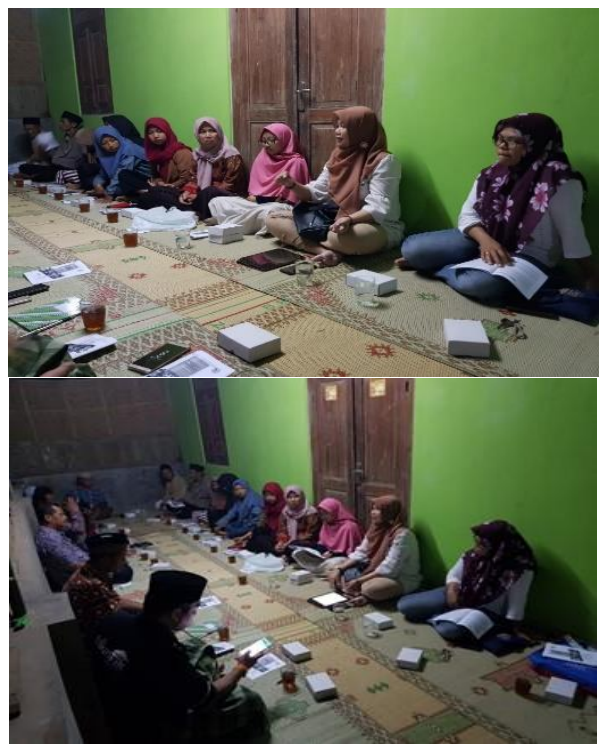

Sosialisasi di lanjutkan dengan pemberiah hibah timbangan pada tim pengelola shodaqoh sampah Dukuh Besole, sebagai alat timbangan pada implementasi shodaqoh sampah.

Gambar 3.

Dokumentasi Penyerahan Timbangan di Dukuh Gerso

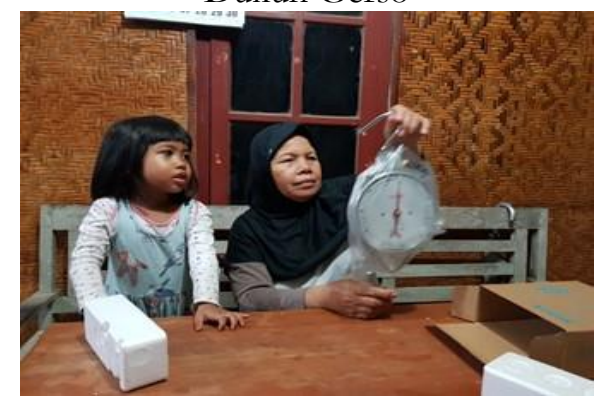


Gambar 4.

Dokumentasi Sosialisasi Shodaqoh Sampah di Dukuh Gerso

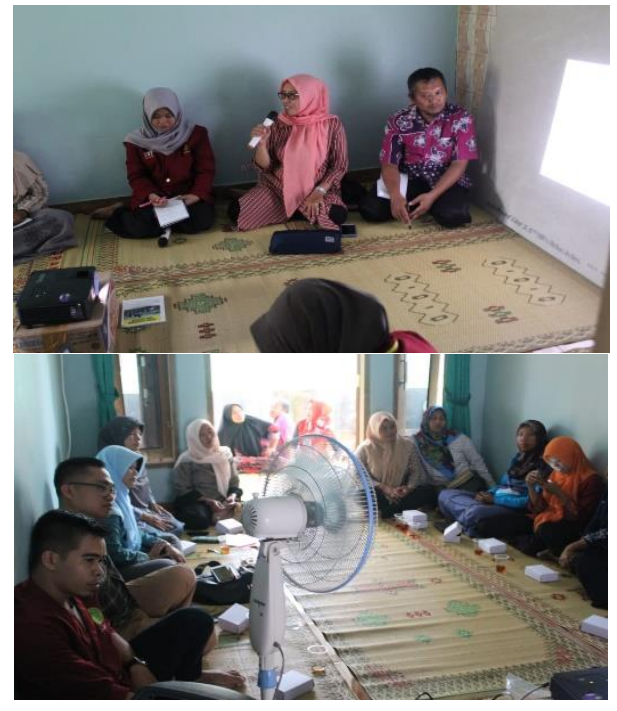

Selanjutnya, sosialisasi di lanjutkan dengan pemberiah hibah timbangan pada tim pengelola shodaqoh sampah Dukuh Gerso, sebagai alat timbangan pada implementasi shodaqoh sampah.

Gambar 5.

Dokumentasi Penyerahan Timbangan di Dukuh Besole

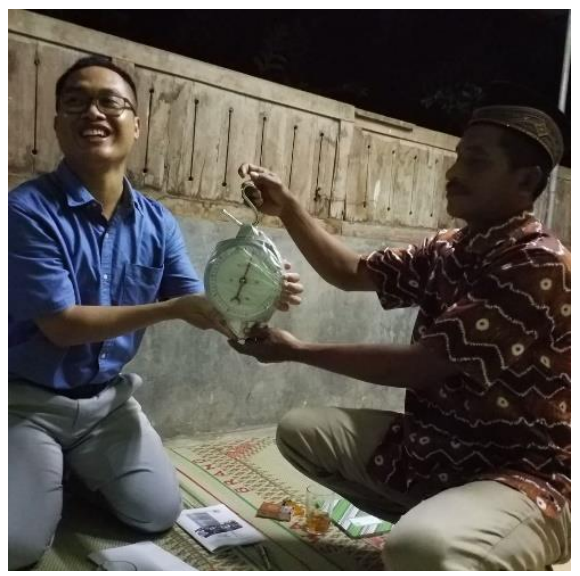

\section{Implemetasi dan Pemilahan Sampah Rumah Tangga}

Tahap berikutnya adalah praktek atau implementasi pemilahan sampah rumah tangga, yaitu memisahkan dan memilih atau memilah antara sampah kertas, sampah plastik, dan sampah logam/gelas. Dengan antusias warga masyarakat maka upaya mempraktekkan penyuluhan shodaqoh sampah ini berjalan dengan baik dan tidak ada kendala apapun.

Pemilahan sampah ini dilakukan bertujuan untuk mempermudah pengelolaannya, sehingga lebih mudah memilah-milah sampah mana saja sesuai dengan pemanfaatannya.

Selanjutnya, setelah sampah terpisah antara sampah kertas, sampah plastik, dan sampah logam/gelas dapat di setorkan kepada pengurus atau tim pengelola untuk di kelola lebih lanjut. Dengan demikian seiring dengan kebermanfaatan sampahsampah tersebut dan kebersihan lingkungan sekitar, akan menjadi shodaqoh tersendiri bagi warga masyarakat yang telah ikut serta dalam keberlangsungan pelaksanaan shodaqoh sampah.

Berikut tata cara shodaqoh sampah.

1) Setiap warga atau rumah tangga menyediakan setidaknya 3 karung yang masing-masing untuk menampung sampah yang sudah di pilah selama waktu sampai penuh sampah/limbah rumah tangganya.

2) Setiap warga atau rumah tangga memilah dan memasukkan sampah (kondisi bersih) setiap kali menghasilkan sampah kedalam masing-masing karung sesuai jenis sampah (sampah kertas, sampah plastik, dan sampah logam/gelas)

3) Setiap warga atau rumah tangga menyerahkan sampah yang telah terkumpul kepada pengeurus atau tim pengelola Shodaqoh Sampah, dengan mengirimkankan secara langsung atau menghubungi via sms/telepon untuk diambil oleh

4) Petugas memberikan tanda bukti penyerahan sampah kepada waraga masyarakat yang menyetor sampah dan mencatat dalam buku register.

5) Petugas memasukkan dan menyimpan sampah sesuai jenisnya

6) Selanjutnya, petugas menghubungi dan menjual semua sampah kepada Pengepul. 
7) Pengelola menyalurkan uang hasil penjualan sampah kepada orangorang yang berhak menerimanya.

8) Pengelola membuat dan menyampaikan laporan tertulis kalkulasi hasil penjualan sampah dan penyalurannya kepada masingmasing warga masyarakat atau jamaah yang menyerahkan shodaqoh sampah secara berkala.

Berikut dokumentasi implementasi praktek pemilahan sampah berdasarkan jenisnya melalui kegiatan field trip dan kunjungan shodaqoh sampah di Padukuhan Brajan Kecamatan Kasihan.

\section{Field Trip ke Lokasi Pengelolaan Shodaqoh Sampah}

Sebagai kelanjutan atas keberlanjutan program shodaqoh sampah di Desa Trimurti, Arie Kusuma Paksi dan Nanik Prasetyoningsih selaku dosen pendamping dan sekaligus promotor gerakan shodaqoh sampah di Dukuh Besole dan Dukuh Gerso. Kunjungan lapangan dan koordinasi dengan tim pengelola di lakukan secara berkala bertujuan dapat memantau kegiatan shodaqoh sampah dan mengetahui kendalakendala yang dihadapi.

Kegiatan ini berharap juga dapat dilakukan oleh dukuh-dukuh yang lain sebagai bentuk kepedulian warga masyarakat terhadap lingkungan hidup dan kebiasaan masyarakat untuk melakukan sedekah atau shodaqoh meskipun dari hal kecil, serta berfikir kebermanfaatan sumberdaya apapun yang ada di sekitar kita.

Gambar 6.

Dokumentasi Field Trip dan Praktek Pemilahan Sampah oleh Masyarakat Dukuh Gerso

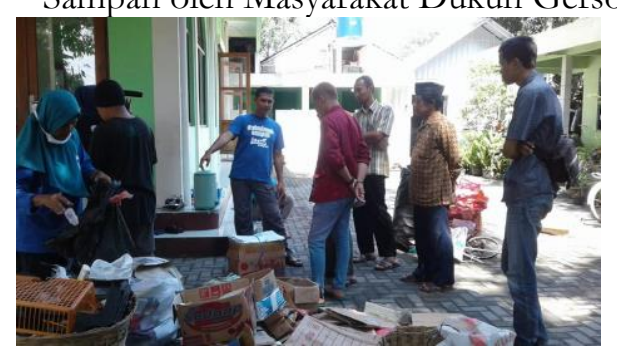

Gambar 7.

Dokumentasi Field Trip dan Praktek Pemilahan Sampah oleh Masyarakat Dukuh Besole

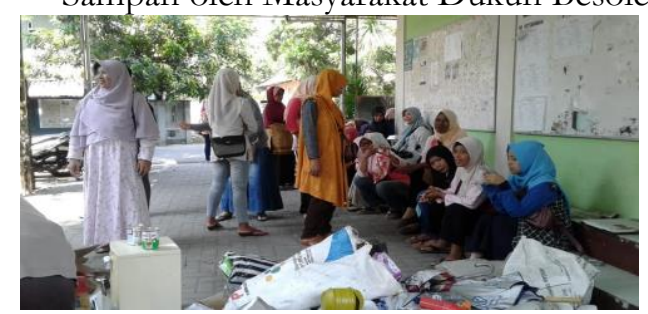

\section{HASIL DAN PEMBAHASAN}

Permasalahan sampah sesungguhnya permasalahan setiap warga masyarakat secara bersama-sama. Hal ini karena setiap diri warga masyarakat memiliki andil dalam produksi sampah yang ada dalam kehidupannya. Dengan demikian, setiap warga masyarakat senantiasa turut serta bertanggungjawab terhadap sampah yang telah diproduksinya, sehingga sampah itu tidak mempunyai dampak buruk bagi kehidupan warga masyarakat secara luas.

Oleh karnanya, Setiap warga masyarakat seharusnya dapat berlaku bijak (wise) dalam memperlakukan sampah, tidak sembarang membuangnya sehingga berdampak buruk bagi kehidupan ekosistem makhluk hidup di sekitarnya.

Warga masyarakat Dukuh Basole dan Dukuh Gerso adalah bagian dari warga masyarakat yang mempunyai paradigma bahwa sampah adalah sesuatu yang tidak ada gunanya sehingga harus di buang jauh-jauh dari lingkungannya sehingga banyak warga yang meremehkannya. Sehingga, tidak ada upaya dan pemikiran untuk mengelola sampah dengan benar dikarenakan sampah adalah sesuatu yang sudah tidak ada gunanya juga kotor dn harus di buang bahkan di sirnakan dengan membakar sembarangan sampah-sampah rumah tangga.

Tanpa disadari di sekitar lingkungan keluarga telah mengajarkan bahwa membuang sampah sembarangan adalah suatu hal yang lumrah maka secara tidak langsung mengajarkan pada anak-anak untuk melakukan apa yang telah dilakukan dengan mengamati kebiasaan lingkungan sekitar. Saat kebiasaan ini menjadi suatu 
keyakinan yang dianggap benar karena seringnya perilaku itu terjadi, tentu akan semakin sulit untuk merubah paradigma lama ini, karena paradigma tentang sampah sudah menjadi asumsi yang dianggap benar.

Berangkat dari permasalahan tersebut pengabdian dengan tema shodaqoh sampah ini di galakkan di desa Trimurti. Warga masyarakat desa Trimurti sangat terlihat antusian untuk menerima dan melaksanakan program Shodaqoh sampah ini. Hal ini terliht dengan keterlibatan warga masyarakat untuk mengikuti dari mulai sosilisasi dan penyuluhan sampai dengan praktek langsung bagaiaman melaksanakan kegiatan shodaqoh sampah.

Berikut dokumentasi bentuk partisipasi warga pada kegiatan praktek pelaksanaan kegitan Shodaqoh Sampah.

Gambar 8.

Dokumentasi Partisipasi Warga pada Kegiatan Praktek Pelaksanaan Kegiatan Shodaqoh Sampah

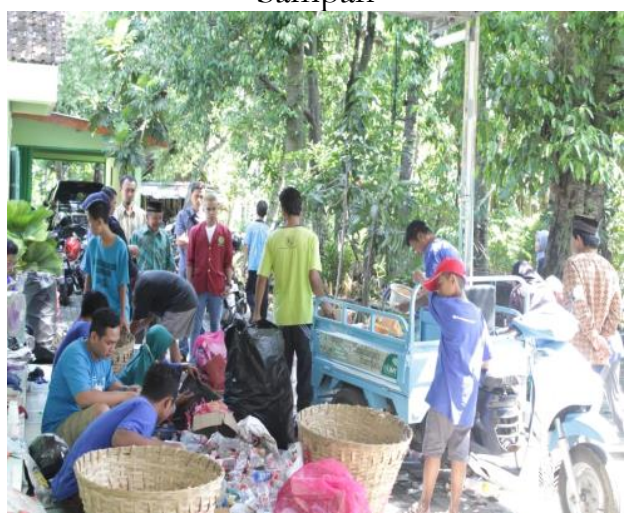

Berdasarkan dokumentasi diatas, terlihat jelas antusias dan ketulusan warga dalam menggalakkan kegiatan shodaqoh sampah supaya bias diterapkan di Desa Trimurti khususnya di Dukuh Basole dan Dukuh Gerso. Terlihat juga bagaimana paradigma mereka yang semula menganggap bahwa sampah adalah sesuatu yang sudah tidak ada kegunaannya dan harus di jauhkan dari lingkungan dengan membakar tumpukan semua sampah rumah tangga bergeser menjadi anggapan sampah ada sesuatu yang bermanfaat yag bisa dijadikan sarana amal zakat yang dapat menjadi kegiatan shodaqoh rutin. Di samping itu sampah juga menjadi lahan ibadah yang mudah yaitu menjadikan amal jariyah, kegiatan saling tolong-menolong (ta'awnn), dan saling menanggung (takaful).

Ibadah lain dari bershodaqoh adalah mereka telah membiasakan lingkungan yang bersih, karena kebersihan adalah salah satu ibadah yang dianjurkan agama Islam.

Hal lain dari bentuk keterbukaan dan rasa tanggugjawab dari warga masyarakat Dukuh Basole dan Dukuh Gerso adalah berbagai kegiatan ini dilaksanakan agar masyarakat mampu memahami tentang pentingnya menjaga kebersihan, meningkatkan pemahaman masyarakat tentang cara mengelola limbah sampah, memampukan masyarakat memilah sampah dan memanfaatkannya untuk shodaqoh, masyarakat mampu membentuk pengelola shodaqoh sampah secara mandiri dan masyarakat mengetahui praktek pengelolaan shodaqoh sampah dan pengelolaan serta pemilahan sampah, membentuk kepanitiaan sebagai tim pengelola shodaqoh sampah. Kepanitian ini terbentuk dengan suka rela dengan kesadaran warga masyarakat tanpa ada unsur paksaan. Tim pengelola ini bertugas untuk mengkoordinir kegiatan shodaqoh sampah agar berjalan dengan baik dan berkelanjutan.

Adapun susunan kepengurusan Struktur Pengurus Shadaqah Sampah adalah sebagai berikut.

- Ketua : Novian Pandu Jatmiko

- Sekretaris : Monicha Intan Mayrani

- Bendahara : Dwi Nofi Qusrini

- Divisi Humas dan Penyaluran

- Afnan Sa'ud hanifuddin

- Ari Sutrisno

- Febri Fitrianto

- Devisi Pemilahan dan Penjualan

o Fika Nur Wahyuni

o Suismiyati 
- Dhimas Galih Febriana

○ Novita Triharyanti

- Devisi Logistik:

\section{○ Fendy Dwi Santoso \\ - Arinda Salsa Oktarinsa}

Dengan terbentuknya struktur tersebut diharapkan masalah kebersihan di Dukuh Gerso dapat tertangani dan kegiatan bank sampah ataupun shadaqah sampah dapat berjalan meskipun program pengabdian masyarakat sudah selesai. Selain itu diharapkan pula, adaya pengawasan dari pihak universitas terkait kegiatan bank sampah/shadaqah sampah yang terlaksana di Dukuh Gerso untuk selanjutnya dijadikan kegiatan jangka panjang yang dapat diampu untuk program pengabdian masyarakat selanjutnya. Selanjutnya untuk Dukuh Besole, kegiatan shodaqoh sampah baru sebatas inisiasi, Kepala Dukuh dan masyarakat sedang dalam proses mempersisapkan sarana dan prasarana untuk melaksanakan kegiatan shodaqoh sampah di Dukuh Besole.

\section{Rencana Tindak Lanjut}

Sesuai dengan harapan pihak masyarakat, meskipun telah dibentuk struktur kepengurusan kepengurusan shodaqoh sampah di tingkat rukun tetangga (RT), perlu diadakan program pengabdian masyarakat lanjutan yang fokus pada pendampingan pelaksanaan kegiatan gerakan shodaqoh sampah demi kelancaran dan keberlanjutan program tersebut. Apalagi, setelah belajar dari pengalaman pengelolaan gerakan yang sama yang ada di Dukuh Brajan, Tamantirto, gerakan shodaqoh sampah memerlukan komitmen yang kuat dari banyak pihak, termasuk dukungan dari kampus seperti Universitas Muhammadiyah Yogyakarta yang mengalokasikan dana pengabdian guna mendukung program pengelolaan sampah melalui inisiasi gerakan shodaqoh sampah.
Demi efektivitas dan keberlanjutan program shodaqoh sampah, pelaksanaan kegiatan selanjutnya perlu menitik beratkan pada pengelolaan shodaqoh sampai ditingkat RT dengan diketuai oleh ketua RT di masing-masing wilayah, dan dengan koordinasi langsung dengan Kepala Dukuh Gerso dan Besole.

\section{KESIMPULAN}

Kesimpulan dari pengelolaan shodaqoh sampah di Dukuh Besole dan Dukuh Gerso adalah sebagai berikut.

1. Sikap yang apatis warga masyarakat Dukuh Besole dan Dukuh Gerso terhadap sampah di fase awal gerakan shodaqoh sampah

2. Terdapat kerjasama yang baik antara tokoh masyarakat dengan warga masyarakat dalam keberlangsungan kegiatan shodaqoh sampah

3. Warga masyarakat Dukuh Besole dan Dukuh Gerso menyambut dengan antusias dan turut serta berpartisipasi dari mulai kegiatan sosialisasi, penyuluhan, sampai praktek dalam mengimplementasikan kegiatan shodaqoh sampah

4. Kesediaannya segenap warga untuk menjadi tim pengelola tanpa ada paksaan

5. Warga masyarakat Dukuh Besole dan Dukuh Gerso berkomitmen tinggi untuk melanjutkan dan membudidaya kegiatan shodaqoh sampah

\section{Saran}

Saran dan rekomendasi dari pengelolaan shodaqoh sampah di Dukuh Besole dan Dukuh Gerso adalah sebagai berikut.

1. Perlu adanya komunikasi yang lebih intensif antara pengurus atau tim pengelola dengan warga masyarakat untuk memberikan pemahaman akan pentingnya manajemen pemilahan sampah secara berkelanjutan agar kegitan dapat berjalan dengan lancar.

2. Untuk keberlanjutkan masih 
diperlukan pendampingan dan pengembangan lebih lanjut khususnya program shodaqoh sampah.

3. Agar program dapat berjalan dengan maksimal maka walaupun program PPDM ini telah selesai dijalankan tetapi masih perlu direncanakan program kerja melalui berdiskusi dengan masyarakat secara langsung agar mendapat hasil yang memuaskan untuk semua pihak

4. Pusat maupun Daerah hendaknya memberikan perhatian pada pola pendekatan baru dalam pengelolaan sampah, salah satunya adalah dengan pendekata agama.

5. Pemerintah Pusat maupun Daerah membantu untuk mensosialisasikan gerakan shodaqoh sampah kepada masyarakat umum.

\section{UCAPAN TERIMAKASIH}

Atas terselenggaranya kegiatan pengabdian ini maka pengabdi mengucapkan terimakasih kepada:

1. LP3M UMY

2. Pemdes Trimurti

3. Dinas Lingkungan Hidup Kabupaten Bantul

4. Padukuhan Gerso

5. Padukuhan Besole

\section{DAFTAR PUSTAKA}

Peet, R., Robbins, P., \& Watts, M. (Eds.). (2011). Global political ecology. Abingdon: Routledge.

Peraturan Pemerintah Nomer 81 Tahun 2012 Tentang Pengelolaan Sampah Rumah Tangga dan Sampah Sejenis Sampah Rumah Tangga

Republik Indonesia, Undang-Undang Nomor 18 Tahun 2008 Tentang Pengelolaan Sampah

Wijayanti, W. P. (2013). Peluang pengelolaan sampah sebagai strategi mitigasi dalam mewujudkan ketahanan iklim kota Semarang. Jurnal Pembangunan Wilayah dan Kota, 9(2), 152 162. 